( Курченко А.І., Ніколаєнко О.М., Федорук Г.В., Халдеева А.Е, 2021

doi:10.37321/immunology.2021.3-06

УДК 612.017.: [.61 - 008]: 57.083.3: [.615: 612.017.1]: 616- 022: 578.825.1

\title{
ВПЛИВ ПРЕПАРАТУ ЕРБІСОЛ УЛЬТРАФАРМ НА ПОКАЗНИКИ КЛІТИННОГО ІМУНІТЕТУ ПРИ ЧАСТО РЕЦИДИВУЮЧІЙ ГЕРПЕСВІРУСНІЙ ІНФЕКЦІї.
}

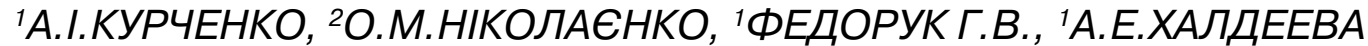 \\ ${ }^{1}$ Національний медичний університет ім. О.О.Богомольця, кафедра клінічої імунології \\ та алергології з основами медичної генетики, ${ }^{2} \mathrm{HПЦ} \mathrm{«Ербіс»,} \mathrm{м.Київ.}$
}

За даними ВООЗ, захворювання, викликані вірусом простого герпесу, займають 2-е місце $(15,8 \%)$ після грипу (35,8\%). Носіями вірусів простого герпесу 1 і 2 типів (ВПГ-1 і ВПГ-2) є 70$90 \%$ населення планети. Клінічні прояви ВПГ1/2-інфекції варіюють від ізольованих уражень шкіри, слизових оболонок, периферичної та центральної нервової системи до дисемінованої мультиорганної патології. Хронічний рецидивуючий перебіг ВПГ-1/2-інфекції обумовлюється недостатністю різних ланок імунної системи та її нездатністю елімінувати вірус з організму. Антитіла до ВПГ, які зберігаються протягом усього життя, іноді в досить високих титрах, не попереджують виникнення рецидивів. Повна елімінація вірусу з організму неможлива, внаслідок унікальної здатності герпесвірусів формувати стан латентності в нейронах регіонарних гангліїв. Необхідно мати доказовий контроль над інфекцією, що досить складно, оскільки внаслідок тривалої персистенції вірусу виникає стан функціональної імунологічної недостатності. Широке застосування ациклічних нуклеозидів повністю не вирішує дану проблему, тому часті рецидиви визначають необхідність патогенетичного лікування, спрямованого на корекцію дефектів імунної відповіді. У великій мірі характер перебігу, частоту та інтенсивність рецидивів герпетичної інфекції визначає стан клітинного імунітету, пов'язаний з Т- і NK-лімфоцитами.

Препарат Ербісол УЛЬТРАфарм (виробник ТОВ «Ербіс») відноситься до групи імуномодулятрів за кодом ATC L03A X+ та до противірусних засобів системного застосування за кодом АТЧ О5. За Інструкцією до препарату і за даними різних дослідників препарат активує імунну систему та прискорює відновлення клітин і тканин. Доказово є дієвим при герпес вірусній інфекції. Основний імуномодулюючий ефект реалізується через дію на NK-клітини (CD3-16+56+) та Т-кілери (CD3+16+56+), а також через макрофагальну ланку, яка відповідає за репарацію пошкоджених клітин та відновлення функціональної активності органів і тканин. В той же час Ербісол УЛьТРАфарм чинить імунокорегуючу дію і при порушеннях імунного статусу сприяє його нормалізації, активуючи лімфоцити, Th1- хелпери і Т-кілери, що особливо важливо для відновлення баланса між клітинним та гуморальним імунітетом при онкозахворюваннях і алергічних процесах. В залежності від стану імунної системи організма, препарат корегує рівень інших факторів імунітету: індукує синтез $\alpha-; \beta$-; $\gamma$-інтерферонів, фактора некрозу пухлин, інтерлейкіну-2 і інтерлейкіну-12, інгібує синтез інтерлейкіну- 10.

Метою данного дослідження було визначення впливу препарату Ербісол-УЛьТРАфарм на клітинну ланку імунної системи (CD3-дозволяє виявити зрілі Т-клітини спокою (неушкоджені) і розрахувати загальну кількість Т-лімфоцитів; CD4-маркер Т-хелперів/індукторів; CD8глікопротеїн, виявлений на поверхні тимоцитів і Т-лімфоцитів, що беруть участь у розпізнаванні антигенних пептидів в контексті молекул основного комплексу гістосумісності класу І, комбінація CD3+CD8+CD45+ маркує Т-цитотоксичні лімфоцити (T-CTL); CD19 - В-лімфоцити, CD56 - справжні «природні кілери» (клітини NK) -в імунограмі - CD3-CD56+CD45+, з оцінкою експресії активуючих CD314/NKG2D та інгібуючих CD94 / NKG2A рецепторів на Т-лімфоцитах у хворих на часто рецидивуючу герпесвірусну інфекцію (ЧРГ).

\section{МАТЕРІАЛ I МЕТОДИ ДОСЛІДЖЕННЯ}

Дослідження проведене з включенням 20 хворих на ЧРГ (з позитивними ІФА та ПЛР аналізами до відбору в групу дослідження) із загостренням 5-6 разів на рік, та 15 практично здорових донорів без клінічних проявів герпесної інфекції на протязі життя. Всі хворі отримували стандартну рекомендовану терапію - місцево препарат валацикловір та внутрішньо м'язево препарат Ербісол Ультрафарм за рекомендованою виробником схемою:

1-й день курсу в/м 1 раз на день по 2 мл увечері, 2-й та 3-й день в/м 2 рази на день по 2 мл вранці та ввечері, а далі, 4-10 дні призначали в/м 2 рази на день по 4 мл (2 ампули) вранці і 2 мл (1 ампула) увечері і потім 2 дні (11 і 12 день) в/м 2 рази на день по 2 мл вранці та ввечері. Усього за 12 днів курсу було призначено 30 ампул препарату Ербісол УЛьТРАфарм. Ін'єкції препарату 
ЕРБІСОЛ УЛЬТРАфарм призначали натще, тобто, за 1-2 години до їжі або через 2-3 години піс- ля їжі (чай, соки, воду тощо можна було вживати у будь-який час).

\section{0 ампул Ербісол® УЛЬТРАфарм (у)}

\begin{tabular}{|c|c|c|c|c|c|c|c|c|c|c|c|c|}
\hline 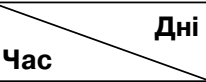 & 1 & 2 & 3 & 4 & 5 & 6 & 7 & 8 & 9 & 10 & 11 & 12 \\
\hline $600-900$ & & $\mathrm{y}$ & $y$ & $2 y$ & $2 \mathrm{y}$ & $2 \mathrm{y}$ & $2 y$ & $2 y$ & $2 \mathrm{y}$ & $2 y$ & $\mathrm{y}$ & $\mathrm{y}$ \\
\hline $2100-2400$ & $y$ & $y$ & $y$ & $\mathrm{y}$ & y & y & y & $\mathrm{y}$ & $\mathrm{y}$ & $\mathrm{y}$ & $\mathrm{y}$ & $\mathrm{y}$ \\
\hline & \multicolumn{3}{|c|}{3 дні } & \multicolumn{7}{|c|}{7 днів } & \multicolumn{2}{|c|}{2 дні } \\
\hline
\end{tabular}

До початку та на 21 день від початку терапії проводилось дослідження клітинної ланки імунітету - імунограмма з визначенням CD3, CD4, CD8, CD19, CD56, CD314 та CD94.

Субпопуляційний склад лімфоцитів периферійної крові досліджували методом протокової цитометрії за допомогою реагентів для визначення кластерів диференциації виробництва «Beckman Coulter Inc.», США (Cyto-Stat тетраХPOM CD45FITC/CD4-RD1/CD8-ECD/CD3-PC5, CYTO-STAT тетраCHROME CD45-FITC, CD56-RD1, CD19-ECD, CD3-PC5, IOTest CD56-PC5, IOTest CD3-FITC, CD314-APC, CD94-PE, IOTest CD45-PC7).

По 100 мкл периферичної крові з КЗЕДТА в якості антикоагулянту інкубували протягом 1520 хвилин в захищеному від світла місці, з сумішами кон'югованих моноклональних антитіл:

1. До CD45, мічене флуоресцентним барвником FITC, до CD 56, мічене флуоресцентним барвником RD1, до CD 19, мічене флуоресцентним барвником ECD, та до CD 3, мічене флуоресцентним барвником РС5, в одному флаконі (Тетра1) та моноклональне антитіло до CD 314, мічене флуоресцентним барвником APC, CD 94, мічене PE (фікоеритрином).

2. До CD45, мічене флуоресцентним барвником FITC, до CD 4, мічене флуоресцентним барвником RD1, до CD 8, мічене флуоресцентним барвником ECD, та до CD 3, мічене флуоресцентним барвником РС5, в одному флаконі (Тетра2) та моноклональне антитіло до CD 314, мічене флуоресцентним барвником APC, CD 94, мічене PE (фікоеритрином).

3. До CD3, мічене флуоресцентним барвником FITC, до CD94, мічене флуоресцентним барвником PE, до CD56, мічене флуоресцентним барвником PC5, до CD45, мічене флуоресцентним барвником PC7, до CD 314, мічене флуоресцентним барвником APC, CD 94, мічене РЕ (фікоеритрином).

Після інкубації проводили лізис еритроцитів за допомогою лізуючого розчину, відмивали і ресуспендували клітини крові в фосфатно-сольовому буфері (РВC). Для визначення абсолютних значень додавали 100 мкл. флюоросфер Flow-Count виробництва «Beckman Coulter Inc.»,
США. Цитофлуорометричний аналіз виконували на проточному цитометрі NAVIOS («Beckman Coulter Inc.»). В результатах аналізу відображали такі показники (в процентах та абсолютних значеннях):

1. CD3-19+, CD3-16\&56+, CD3+16\&56+, CD3+19-, CD3+4+, CD3+8+, CD4+/CD8+.

2. Показник експресії CD 314+ та CD 94+ в процентах та абсолютних значеннях, визначали окремо: серед всіх лімфоцитів та на натуральних кіллерах (CD 3- 56+ 314+, CD 3- 56+94+).

Серед всіх NK маркованих CD 3-56+ (прийнятих за $100 \%$ ) - процент клітин, що не мають експресії жодного 3 вищевказаних маркерів, позитивні тільки за CD 314+ і позитивні за обома рецепторами (CD 3- 56+314+94+). Серед Т-лімфоцитів 3+ визначали окремо процент Т-клітин, які не марковані жодним рецептором, позитивні за CD 314+ та позитивні за обома рецепторами (CD 3+56+314-94-, CD 3+56+ 314+94-, CD 3+56+314+94+).

\section{РЕЗУЛЬТАТИ ДОСЛІДЖЕННЯ ТА ОБГОВОРЕННЯ}

Всі паціенти, які отримали препарат Ербісол ульТРАфарм констатували поліпшення загального самопочуття. Клінічно виражені симптоми у вигляді пухирцевих висипів зменьшувались за площею ураження та проявах болі та свербіжу в порівнянні з попереднім загостренням. За 3-місячний термін подальшого спостерігання нових рецидивів не виявлено.

У всіх пацієнтів результати загальної імунограми знаходились в межах широких коливань норми. Особливістю, практично у всіх хворих на ЧРГ, були зміни в показниках експресії CD314+та CD94+ і на NK-, і на Т-цитотоксичних клітинах.

1. Співвідношення на NK - клітинах експресованих CD 314+ до CD 94+ (CD 3- 56+ 314+ до CD 3- 56+ 94+) складало 4,6 - 5,2 до початку лікування и знижувалось до $3.2-3.5$ на 21 день від початку терапії. Важливою особливістю $є$ зниження проценту NK-клітин негативних за експресією CD314+ і CD94+ (CD356+314-94-) та, відповідно, збільшення - позитивних (CD3-56+314+94+) 
Серед всіх NK 3-56+ (прийнятих за 100 \%), дослідження показало зниження відсотків CD3-56+314-94- та збільшення CD3-56+314+94+

\begin{tabular}{|c|c|c|c|}
\hline CD & $\begin{array}{c}\text { \% від загальної кількості } \\
\text { КК до лікування }\end{array}$ & $\begin{array}{c}\text { \% від загальної } \\
\text { кількості NК після } \\
\text { лікування }\end{array}$ & Коефіцієнт зміни \\
\hline CD 3- 56+314-94- & $3.8-4,7$ & $1,4-1,8$ & 3,2 \\
\hline CD 3- 56+314+94- & $74.2-78,0$ & $68,0-71,2$ & 1.2 \\
\hline CD 3- 56+314+94+ & $18.3-21,4$ & $28,5-29,4$ & 1,37 \\
\hline
\end{tabular}

Приклад змін експресії CD 314 та CD 94 на NK-клітинах у хворих на ЧРГ до та після лікування препаратом Ербісол УЛЬТРАфарм.

До лікування

[N AND M] FL4 PEAK LOG/FL6 PEAK LOG

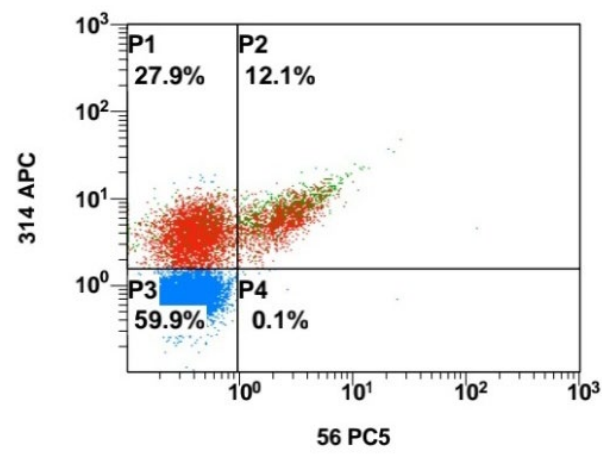

1. P1- Q1 - CD 3- 56+314+94+; P2- Q2- CD 3$56+314-94-; P 3-Q 3-C D$ 3- 56+ 314+94-
Після лікування

[M AND J] FL2 PEAK LOG/FL6 PEAK LOG

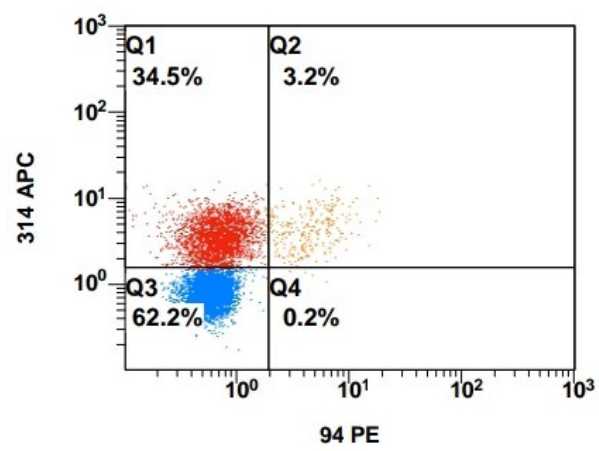

2. Зміни Т-цитотоксичних клітин з експрессією CD 314+ по відношенню до CD 94+ мали активуючий тип та в середньому збільшились в 1,2 раза.

Таблиця 2

Співвідношення CD 3+ 314+ и CD 3+ 94+ в середньому складало 7,6 до початку лікування та 8,5 після. В середньому обидва показника збільшились в 1,2 раза.

\begin{tabular}{|c|c|c|c|}
\hline т-лімфоцити 3+ & $\begin{array}{c}\text { \% від загальної кількості } \\
\text { лімфоцитів до лікування }\end{array}$ & $\begin{array}{c}\text { \% від загальної кількості } \\
\text { лімфоцитів після } \\
\text { лікування }\end{array}$ & $\begin{array}{c}\text { Коефіціент } \\
\text { зміни }\end{array}$ \\
\hline CD 3+314+ & 23,9 & 29,2 & 1.22 \\
\hline CD 3+94+ & 2,8 & 3,43 & 1.2 \\
\hline
\end{tabular}

Приклад змін на T-цитотоксичних лімфоцитах експрессії CD314 i CD94 (CD3+314+ та CD3+94+)

До лікування

[N AND M] FL1 PEAK LOG/FL2 PEAK LOG

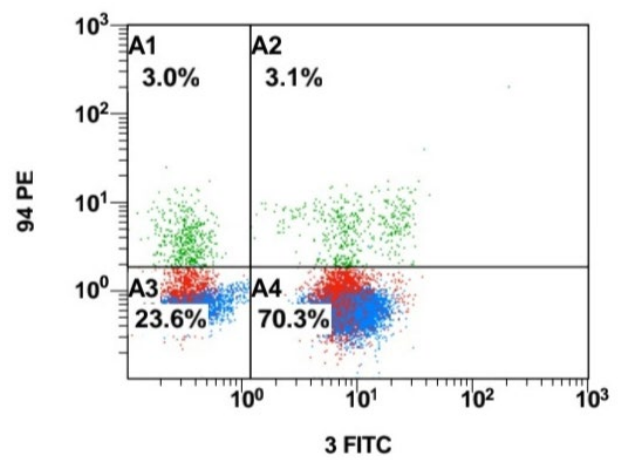

Після лікування

[M] FL1 PEAK LOG/FL2 PEAK LOG

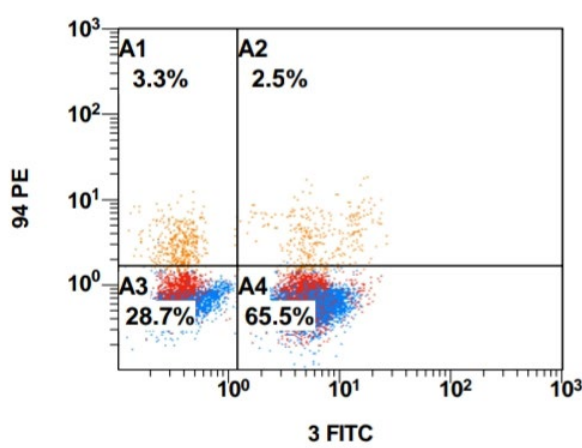

A1- CD94 на Т-цитотоксичних клітинах 
[M] FL1 PEAK LOG/FL6 PEAK LOG

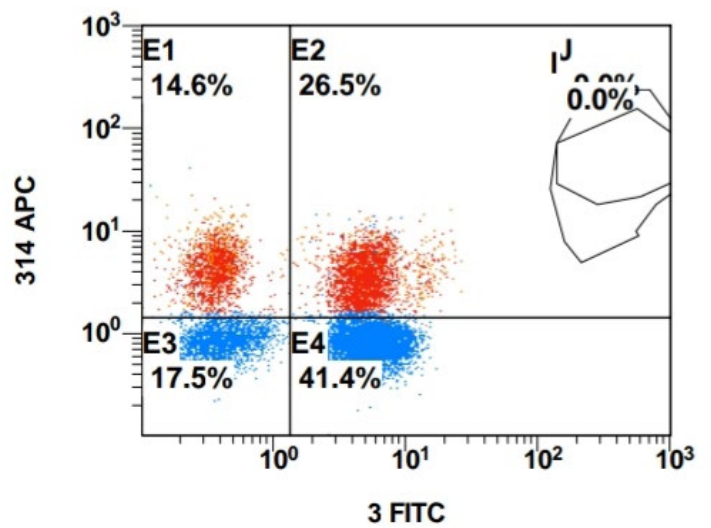

[N AND M] FL1 PEAK LOG/FL6 PEAK LOG

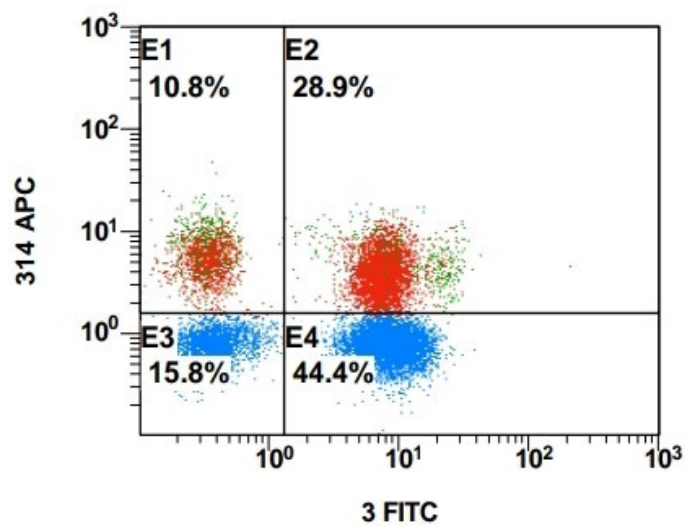

E2 - CD314 на Т-цитотоксичних клітинах

3. Серед всіх клітин NK та Т-цитотоксичних $(\mathrm{CD} 3+56+)$ значущим є збільшення позитивних за експресією обох рецепторів лімфоцитів
(CD3+56+314+94+) та зменшення негативних (CD3+56+314-94-). При цьому клітини з експресією тільки CD314+ також збільшились.

Збільшення CD 3+56+314+94+ в 1,5 раза та зменшення CD 3+56+314-94- серед всіх

Таблиця 3 Т-лімфоцитів 3+ (прийняті за $100 \%$ )

\begin{tabular}{|c|c|c|}
\hline CD & $\begin{array}{c}\text { \% від загальної кількості Т-лімфоцитів } \\
\text { до лікування }\end{array}$ & $\begin{array}{c}\text { \% від загальної кількості Т-лімфоцитів } \\
\text { після лікування }\end{array}$ \\
\hline CD 3+ 56+314-94- & 65,2 & 60,4 \\
\hline CD 3+56+314+94- & 34,5 & 35,4 \\
\hline CD 3+56+314+94+ & 3,2 & 4,8 \\
\hline
\end{tabular}

Приклад змін CD3+56+314+94+ та CD3+56+314-94- у хворих на ЧРГ до та після лікування препаратом Ербісол УЛЬТРАфарм.

До лікування

[M] FL2 PEAK LOG/FL6 PEAK LOG

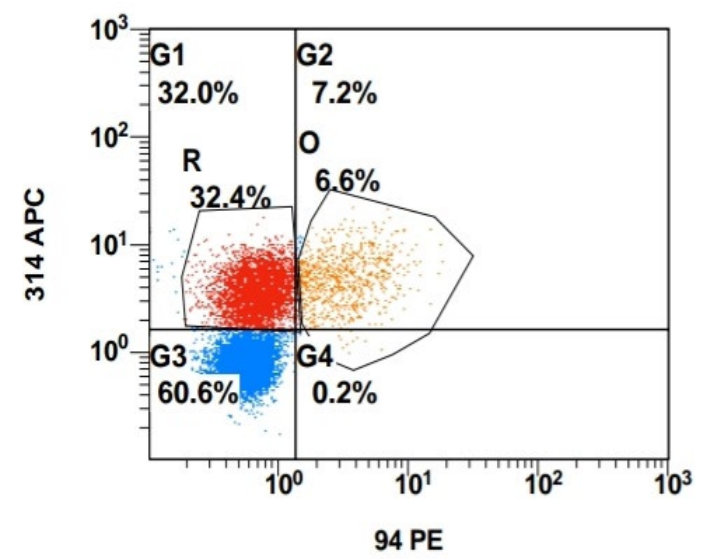

G1 - CD314 на NK і T-клітинах, R- NK i Т-клітини позитивні за CD314, негативні за CD94, O - NK і T-клітини позитивні за CD314 та CD94, G3- негативні за обома рецепторами.

Зміни експресії активуючих та інгібуючих рецепторів CD 314+ та CD 94+ і на NK- і на Т-цитотоксичних клітинах показали активуючий ефект впливу препарату Ербісол УЛьТРАфарм на
Після лікування

[N AND M] FL2 PEAK LOG/FL6 PEAK LOG

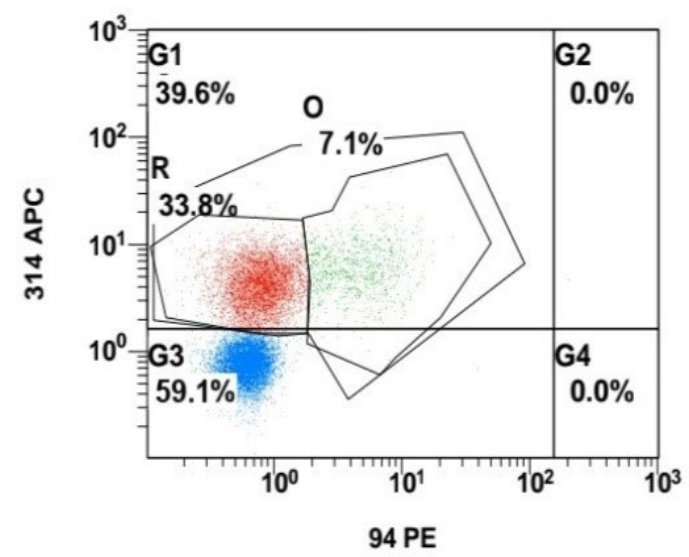

Т-клітинну ланку імунної системи, а динаміка змін кількості та співвідношень активуючих NKG2D (CD314) і інгібуючих CD94 / NKG рецепторів - на ознаки імуноадаптивного ефекту дії препарату.

NK клітини складають 5-20\% лімфоцитів периферичної крові і є одним з ключових компонентів імунної системи, що традиційно відносяться до системи вродженого імунітету. Проявляючи 
цитотоксичну та регуляторну активність, NK клітини розпізнають інфіковані вірусом та пухлинні клітини, які експресують на своїй поверхні сигнали «небезпеки». Протягом тривалого часу вважалося, що NK забезпечують швидку ефекторну відповідь, а зовнішні стимули мало впливають на їх функціонування. Однак за останні роки накопичились дані, що свідчать про наявність у NK- клітин властивостей, які зближують їх з клітинами придбаного (адаптивного) імунітету. Функціональна активність NK $€$ результатом внутрішньоклітинних взаємодій активуючих і інгібуючих процесів. Активація NK-клітин залежить від зсуву в сигнальному балансі між інгібуючими та активуючими рецепторами. Рецептори на поверхні NK розділені на три основних сімейства: рецептори NK-цитотоксичності, лектинові рецептори C-типу (CD94 (NKG2A)) та KIR. Всі рецептори NKцитотоксичності $\epsilon$ активуючими, тоді як лектинові рецептори та KIR можуть бути як активуючі, так і ингібуючими. Придбання в процесі дозрівання NK-клітинами цитотоксичних властивостей синхронізовано з появою самоінгібуючіх рецепторів CD94 (NKG2A) або KIR (кілерних імуноглобуліноподібних рецепторів). NK, позбавлені інгібуючих рецепторів, проявляють не більшу активність, а, навпаки, є гіпореактивними. При розпізнаванні ліганда активуючі рецептори NK можуть впізнати клітину як аномальну і, відповідно, запустити процес її знищення. При цьому ингибуючі рецептори забезпечують також контроль активності NK щодо здорових тканин.

NKG2D (CD314), який кодується KIrk1, являє собою активуючий рецептор клітинної поверхні, який переважно експресується на всіх NK-клітинах, NKT-клітинах та підмножинах Т-клітин. Активуючі рецептори в першу чергу забезпечують спостереження за тканинним стресом - шляхом розпізнавання індукованих стресом власних лігандів на клітинах-мішенях. Молекулярна структура NKG2D дозволяє йому пов'язувати ряд структурно різних МHC-Iподібних лігандів. У гомеостатичних умовах експресія лігандів NKG2D, як правило, низька. Навпаки, при клітинному стресі, такому як інфекція або онкогенна трансформація, їх експресія може бути значно збільшеною.

Основна функція NKG2D полягає в регуляції передачі сигналів через інші рецептори. Його унікальна особливість полягає в тому, що він здатний як пригнічувати, так і посилювати передачу сигналів великої кількості рецепторів в декількох онтологічно різних підмножинах імунних клітин на різних етапах життєвого циклу, таких, як гематопоетичний розвиток, праймування i ефекторні реакції. Запобігає NKG2D загальній гіперреактивності NK-клітин чи встановлює поріг активації конкретного активуючого рецептора NK-клітин, вимагає вивчення.
NKG2D бере участь у формуванні периферичної толерантності NK-клітин - ефект, який вперше був виявлений у онкологічних хворих. Висока експресія ліганду NKG2D опосередковує інгібування рецептора NKG2D на лімфоцитах, інфільтруючих пухлину (TIL), і знижує чутливість до взаємодії NKG2D. Вважається, що в фізіологічних умовах цей процес запобігає гіперреактивності NK проти периферичних лігандів, утворення яких в кістковому мозку є неповним. Однак, коли ліганди NKG2D експресуються хронічно або з низькою інтенсивністю, наприклад, під час вагітності в плаценті, вони повідомляють про необхідність зниження рецепторної реакції і пригнічують функцію імунних клітин. Таким чином, NKG2D, найбільш вірогідно, є сенсором імунологічного контролю, і, відповідним чином, регулятором активності інших рецепторів.

\section{ВИСНОВОК}

Препарат Ербісол УЛьТРАфарм, застосований в схемі лікування часто рецидивуючого герпеса, ефективно впливає на зміни показників експресії CD 314(NKG2D) та CD 94 (NKG2A або KIR) на натуральних кілерах та Т-цитотоксичних клітинах. Отримані результати змін показників клітинного імунітету в динаміці вказують на активуючий вплив препарату, що $є$ основою для подальшого вивчення доказових механізмів взаємовідносин Т-цитотоксичних та NK-клітини при імунозалежних станах за умови використання схем імуномодулюючої терапії препаратом Ербісол УЛЬТРАфарм

\section{ЛITEPATУPA}

1. Дранник Г.Н., Свидро Е.В., Курченко А.И., Вагалюк Л.Н., Фесенкова В.И. Национальный медуниверситет им. А.А. Богомольца, Институт урологии АМН Украины «Влияние Ербисола® ультрафарм при рецидивующей герпетической инфекции на продукцию ИЛ4, ИЛ-10 и експрессию активационных молекул» Журн. Імунологія та алергологія, №2, 2006, стор. 45-47.

2. Дранник Г.Н., Курченко А.И., Фесенкова В.Й., Дягель И.С., Корнилина Е.М., Николаенко А.Н., Гладкий А.В. «Изучение влияния препаратов класса Ербисол® напродукцию цитокинов мононуклеарами периферической крови здоровых доноров и онкологических больных» ВІСНИК ФАРМАКОЛОГІї та ФАРМАЦІї, 2006, № 7, с.29-32.

3. ДранникГ.Н., Курченко А.И., Фесенкова В.И., Николаенко А.Н. «Влияние препарата Ербисол® ультрафарм на продукцию цитокинов у больных рецидивирующей герпетической инфекцией», Журнал Сучасні інфекції, - 2007. - №4. - с. 94-98 
4. Базыка Д.А., Гладкий А.В., Корнилина Е.М., Николаенко А.Н. «Особенности влияния препаратов класса Ербисол® на экспрессию поверхностных маркеров клеток крови здоровых доноров и больных с иммунодепрессией клеточного иммунитета in vitro и в динамике лечения. ВІСНИК ФАРМАКОЛОГІї та ФАРМАЦІї, 2009, № 1, С.39-47

5. Дземан M.І., Дземан Н.A., Ніколаєнко О.М. «Новітня група вітчизняних ендогенних регенераторних біологічних імуномодулюючих середників: теорія, клінічна практика та перспективи». Практикуючий лікар, т.6. №1, c.5-16.

6. Абакушина Е.В., Лысюк Е.Ю., Посвятенко А.В., Кибардин А.В. «Ингибирование экспрессии активирующего рецептора NKG2D на NK-клетках рекомбинантным белком MICA» //Медицинская иммунология, 2017. T.19, №1. с. 81-88. doi: 10.15789/15630625-2017-1-81-88

7. Bae D.S., Hwang Y.K., Lee J.K. Importance of NKG2D NKG2D ligands interaction for cytolytic activity of natural killer cell. Cellular Immunology, 2012, Vol. 276, pp. 122-127.

8. Groh V., Wu J., Yee C., Spies T. Tumourderived soluble MIC ligands impair expression of NKG2D and T-cell activation. Nature, 2002, Vol. 419, pp. 734-738.

9. Martin G.S. Cell signaling and cancer. Cancer Cell., 2003, Vol. 4, pp. 167-174.

10. Pardoll D. Immunology. Stress, NK Receptors, and Immune Surveillance. Science, 2001, Vol.294,pp. 534-538

11. Bendall, S. C. et al. Single-cell mass cytometry of differential immune and drug responses across a human hematopoietic continuum. Science 332, 687-696 (2011).

\section{РЕЗЮME}

ВПЛИВ ПРЕПАРАТУ ЕРБІСОЛ УЛЬТРАФаРМ НА ПОКАЗНИКИ КЛІТИННОГО ІМУНІТЕТУ ПРИ ЧАСТО РЕЦИДИВУЮЧИЙ ГЕРПЕСВІРУСНІЙ ІНФЕКЦІЇ.

${ }^{1}$ Курченко А.І., ${ }^{2}$ Ніколаєнко О.М., 1 Федорук Г.В., ' Халдеева А.Е.

${ }^{1}$ Національний медичний університет ім. О.О.Богомольця, кафедра клінічої імунології та алергології з основами медичної генетики, м.Київ ${ }^{2}$ НПЦ «Ербіс», м.Київ.

Мета дослідження - вивчення впливу препарата Ербісол УЛЬТРАфарм (виробник ТОВ «Ербіс») на клітинну ланку імунної системи при часто рецидивуючій герпес вірусній інфекції.

Матеріали та методи. Обстежено 20 хворих на часто рецидивуючий герпес (з позитивними ІФА та ПЛР аналізами до відбору в групу дослідження) із загостренням 5-6 разів на рік, та 15 практично здорових донорів без клінічних проявів герпесної інфекції на протязі життя. Всі хворі отримували стандартну рекомендовану терапію - місцево препарат валацикловір та внутрішньо м'язево препарат Ербісол Ультрафарм за рекомендованою виробником схемою.

Методом протокової цитофлуориметрії визначено субпопуляційний склад лімфоцитів периферійної крові (CD3, CD4, CD8, CD19, CD56) та експресію активуючих та інгібуючих рецепторів (CD314(NKG2D) і CD94(NKG2A)) на цитотоксичних клітинах з використанням реагентів для визначення кластерів диференциації виробництва «Beckman Coulter Inc.» Цитофлуорометричний аналіз виконували на проточному цитометрі NAVIOS («Beckman Coulter Inc.»).

Результати дослідження. Всі паціенти, які отримали препарат Ербісол УльТРАфарм констатували поліпшення загального самопочуття. Клінічні симптоми хвороби у вигляді пухирцевих висипів зменьшувались за площею ураження та проявах болі та свербіжу в порівнянні з попереднім загостренням. За 3-місячний термін подальшого спостерігання нових рецидивів не виявлено. Зміни експресії активуючих та інгібуючих рецепторів CD 314+ та CD 94+ і на NK- і на Т-цитотоксичних клітинах показали активуючий ефект впливу препарату Ербісол УЛЬТРАфарм на Т-клітинну ланку імунної системи, а динаміка змін кількості та співвідношень активуючих NKG2D (CD314) і інгібуючих NKG2A (CD94) рецепторів - на ознаки імуноадаптивного ефекту дії препарату.

Висновки. Препарат Ербісол УльТРАфарм, застосований в схемі лікування часто рецидивуючого герпеса, ефективно впливає на зміни показників експресії CD314(NKG2D) та CD94 (NKG2A) на натуральних кілерах та Т-цитотоксичних клітинах. Отримані результати змін показників клітинного імунітету в динаміці вказують на активуючий вплив препарату, що $є$ основою для подальшого вивчення доказових механізмів взаємовідносин Т-цитотоксичних та NKклітини при імунозалежних станах за умови використання схем імуномодулюючої терапії препаратом Ербісол УЛЬТРАфарм.

Ключові слова: часто рецидивуючий герпес (ЧРГ), Ербісол УЛьТРАфарм, NK-клітини, CD314, CD94, імуноадаптивний ефект.

\section{PЕЗЮME}

\section{ВЛИЯНИЕ ПРЕПАРАТА ЭРБИСОЛ УЛЬТРАФАРМ НА ПОКАЗАТЕЛИ КЛЕТОЧНОГО ИММУНИТЕТА ПРИ ЧАСТО РЕЦИДИВИРУЮЩЕЙ ГЕРПЕСВИРУСНОЙ ИНФЕКЦИИ}

${ }^{1}$ Курченко А.И., ${ }^{2}$ Николаенко А.Н., ' Федорук Г.В., ' Халдеева А.Е. ${ }^{1}$ Национальный медицинский университет им. А.А.Богомольца, кафедра клинической иммунологии и аллергологии с основами медицинской генетики, г.Киев ${ }^{2}$ НЦП «Эрбис», г. Киев.

Целью исследования было изучение влияния препарата Эрбисол УльТРАфарм (производитель ООО «Эрбис») на клеточное звено иммунной системы при часто рецидивирующей герпетической вирусной инфекции.

Материалы и методы. Обследовано 20 пациентов с часто рецидивирующим герпесом (с положи- 
тельными ИФА и ПЦР-тестами в исследуемой группе) с обострением 5-6 раз в год, и 15 практически здоровых доноров без клинических проявлений герпесной инфекции на протяжении всей жизни. Все пациенты получали стандартную рекомендованную терапию местно препарат валацикловир и препарат для внутримышечного введения Эрбисол Ультрафарм по рекомендованной производителем схеме.

Методом проточной цитофлуориметрии определяли субпопуляционный состав лимфоцитов периферической крови (CD3, CD4, CD8, CD19, CD56) и экспрессию активирующих и ингибирующих рецепторов (CD314(NKG2D) и CD94(NKG2A)) на цитотоксических клетках с использованием реагентов для определения экспрессии дифференциальных кластеров, производства «Beckman Coulter Inc».

Результаты исследования. Все пациенты, получавшие препарат Эрбисол УЛЬТРАФАРМ, констатировали улучшение общего самочувствия. Клинические проявления заболевания уменьшились как по площади поражения, так в проявлениях по сравнению с предыдущим обострением. В течение 3-месячного периода дальнейших рецидивов выявлено не было. Изменения экспрессии активирующих и ингибирующих рецепторов CD 314+ и CD 94+ и на NK- и на Т-цитотоксических клетках показали активирующий эффект влияния препарата Эрбисол УЛЬТРАфарм на Т-клеточное звено иммунной системы, а динамика изменения количества и соотношения экспрессии активирующих CD314(NKG2D) и ингибирующих CD94(NKG2A) рецепторов - на признаки иммуноадаптивного действия препарата.

Выводы. Препарат Эрбисол УЛьТРАФАРМ, применяемый в схеме лечения часто рецидивирующего герпеса, эффективно влияет на изменение показателей экспрессии CD314 (NKG2D) и CD94 (NKG2A) на натуральных киллерах и Т-цитотоксических клетках. Полученные результаты изменений показателей клеточного иммунитета в динамике свидетельствуют об активирующем действии препарата, что является основой для дальнейшего изучения доказательных механизмов взаимоотношений Т-цитотоксических и НК-клеток в иммунозависимых состояниях при условии применения схем иммуномодулирующей терапии с препаратом Эрбисол УЛЬТРАфарм.

Ключевые слова: часто рецидивирующий герпес (ЧРГ), Эрбисол УЛЬТРАфарм, NK-клетки, CD314, CD94, иммуноадаптивний эффект.

\section{SUMMARY}

\section{EFFECT OF ERBISOL ULTRApharm ON CELLULAR IMMUNITY CHARACTERISTICS IN PATIENTS WITH RECCURENT HERPES VIRUS INFECTION.}

$$
{ }^{1} \text { A. I. Kurchenko, }{ }^{2} \text { A.M. Nikolaienko, ' } \text { G.V. Fedoruk, }
$$

$$
{ }^{1} A \text {. Ye. Khaldeeva }
$$

${ }^{1} \mathrm{O}$. Bogomolets National medical university, department of clinical immunology and allergology with medical genetics, Kiev. 2LET "Erbis", Kyiv.

The aim of the study was to detect the effect of Erbisol ULTRApharm on the cellular link of the immune system, thus estimating activating CD314 / NKG2D and inhibiting CD94 / NKG2A receptors in patients with frequently recurrent herpes virus infection.

Material and methods of the study.A total of 15 patients with frequent herpes infection (with positive IFA and PCR tests as the selection criteria), with 5-6 exacerbation episodes a year, and 10 almost healthy people, without clinical manifestations of herpes infection, have been studied. All patients were administered the standard recommended therapy - Valacyclovir locally and Erbisol ULTRApharm intramuscularly, 1 ampoule $\mathrm{i} / \mathrm{m}$ in the morning and evening during 12 days. The peripheral blood subpopulation lymphocytes were detected by flow cytometry using reagents detecting clusters of differentiation of CD3, CD4, CD8, CD19, CD56, CD314(NKG2D) and CD94(NKG2A), produced by «Beckman Coulter Inc.», USA. A flow cytometer NAVIOS («Beckman Coulter Inc.») was used for cytofluorometric analysis.

Results. All patients, administered Erbisol ULTRApharm, were characterized by improved general health. - The clinical symptoms manifestations, represented with blisters and rash, decreased, with reduction of lesion area, pain and itching, compared to the previous exacerbation. No relapses were detected during the subsequent 3-month observation. Modified expression of inducing and inhibiting receptors CD $314+$ and CD 94+ i on NK- i and T-cytotoxic cells manifested inducing effect of the Erbisol ULTRApharm on T-cellular component of the immunity, and modification of quantity and relation of inducing NKG2D (CD314) and inhibiting CD94 / NKG receptors affected the immunoadaptive effect of the drug.

Conclusions. The drug Erbisol ULTRApharm, administered as a component of the treatment scheme for recurrent herpes infection, affects characteristics of expression of CD 314(NKG2D) and CD 94 (NKG2A or KIR) on natural killers and T-cytotoxic cells. The obtained dynamic results of modified characteristics of the cellular immunity evidence about activating effect of the drug, which makes a basis for the subsequent study of evidence-based mechanisms of interaction of T-cytotoxic and NK-cells under immune-dependent conditions, if the immunomodulating therapy includes the drug Erbisol- ULTRApharm.

Key words: frequently recurrent herpes, Erbisol ULTRApharm, NK-cells, CD314, CD94, immunoadaptive effect. 


\section{АВТОРСЬКА ДОВІДКА}

\section{- Курченко A.I.}

д.мед.н., проф., завідувач кафедри клінічної імунології та алергології з секцією медичної генетики Національний медичний університеті імені О.О.Богомольця. 01053, Україна, м.Київ, бульвар

Т.Шевченка, 17 , тел.:+38(050)581-23-45.

\section{- Ніколаєнко О.М.}

д.б.н., директор НПЦ «Ербіс», Ербіс НПЦ, 02002, Украина, Київ, вулиця Раїси Окіпної, 10Б, тел. +38(050)310-22-59

\section{- Федорук Г.В.}

к.м.Н., доцент кафедри клінічної імунології та алергології з секцією медичної генетики Національний медичний університеті імені 0.0.Богомольця. 01053, Україна, м.Київ, бульвар Т.Шевченка, 17 , тел.+38(050)382-98-03

\section{- Халдеєва А.Е.}

лікар- дерматолог, аспірант кафедри клінічної імунології та алергології з секцією медичної генетики Національний медичний університеті імені 0.0.Богомольця 01053, Україна, м.Київ, бульвар

Т.Шевченка, 17,

тел.+38(067)220-16-19

\section{- Курченко А.И.}

д.мед.н, проф,заведующий кафедрой клинической иммунологии и аллергологии с секцией медицинской генетики Национальный медицинский университет им.А.А.Богомольца.

01053, Україна, м.Київ, бульвар

Т.Шевченка, 17 ,

тел.:+38(050)581-23-45.

\section{- Николаенко А.Н.}

д.б.н., директор НПЦ «Эрбис», Эрбис НПЦ, 02002, Украина, Киев, ул. Раисы Окипной, 10Б, тел. +38(050)310-22-59

\section{- Федорук Г.В.}

к.м.н., доцент кафедры клинической иммунологии и аллергологии с секцией медицинской генетики Национальный медицинский университет им.А.А.Богомольца. 01053, Україна, м.Київ, бульвар Т.Шевченка, 17, тел.+38(050)382-98-03

\section{- Халдеева А.Е.}

врач-дерматолог, аспирант кафедры клинической иммунологии и аллергологии с секцией медицинской генетики Национальный медицинский университет им.А.А.Богомольца.

01053, Україна, м.Київ, бульвар

Т.Шевченка, 17 , тел. +38(067)220-16-19

\section{- Kurchenko A.I.}

MD, Prof.,Head of the Department of Clinical Immunology and Allergology with a section of Medical Genetics 0.0.Bogomolets National Medical University. 01053, Ukraine, Kyiv, T.Shevchenko Boulevard, 17, tel.:+38(050)581-23-45.

\section{- Nikolaenko A.N.}

D.Sc. in Biology, director $\mathrm{SRC}$ «Erbis», 02002, Ukraine, Kyiv, Raisa Okipnaia str, 10B, tel.:+38(050)310-22-59

\section{- Fedoruk G.V. ,}

MD, candidate of Medical Sciences, Associate Professor of the Department of Clinical Immunology and Allergology with a section of Medical Genetics 0.0 .Bogomolets National Medical University.

01053, Ukraine, Kyiv, T.Shevchenko Boulevard, 17 , tel.:+38(050)382-98-03

\section{- Khaldieieva A.E}

MD, post-graduate student of Medical Sciences of the Department of Clinical Immunology and Allergology with a section of Medical Genetics 0.0. Bogomolets National Medical University. тел. +38(067)220-16-19 